\title{
Photosynthesis in Extreme Environments
}

\author{
Angeles Aguilera1, Virginia Souza-Egipsy² and Ricardo Amils1,3 \\ ${ }^{1}$ Centro de Astrobiología (INTA-CSIC) \\ ${ }^{2}$ Centro de Investigaciones Agrarias (CSIC) \\ ${ }^{3}$ Centro de Biología Molecular (UAM-CSIC) \\ Spain
}

\section{Introduction}

Our ongoing exploration of Earth has led to continued discoveries of life in environments that have been previously considered uninhabitable. For example, we find thriving communities in the boiling hot springs of Yellowstone, the frozen deserts of Antarctica, the concentrated sulfuric acid in acid-mine drainages, and the ionizing radiation fields in nuclear reactors (González-Toril et al., 2003; Lebedinsky et al., 2007; Pointing et al., 2009). We find some microbes that grow only in brine and require saturated salts to live, and we find others that grow in the deepest parts of the oceans and require 500 to 1000 bars of hydrostatic pressure (Horikoshi, 1998; Ma et al., 2010). Life has evolved strategies that allow it to survive even beyond the daunting physical and chemical limits to which it has adapted to grow. To survive, organisms can assume forms that enable them to withstand freezing, complete desiccation, starvation, high levels of radiation exposure, and other physical or chemical challenges. Furthermore, they can survive exposure to such conditions for weeks, months, years, or even centuries. We need to identify the limits for growth and survival and to understand the molecular mechanisms that define these limits.

Biochemical studies will also reveal inherent features of biomolecules and biopolymers that define the physico-chemical limits of life under extreme conditions. Broadening our knowledge both of the range of environments on Earth that are inhabitable by microbes and of their adaptation to these habitats will be critical for understanding how life might have established itself and survived.

The diversity of life on Earth today is a result of the dynamic interplay between genetic opportunity, metabolic capability, and environmental change. For most of their existence, Earth's habitable environments have been dominated by microorganisms and subjected to their metabolism and evolution. As a consequence of geological, climatologic, and microbial processes acting across geological time scales, the physical-chemical environments on Earth have been changing, thereby determining the path of evolution of subsequent life. For example, the release of molecular oxygen by cyanobacteria as a by product of photosynthesis as well as the colonization of Earth's surface by metazoan life contributed to fundamental, global environmental changes. The altered environments, in turn, posed novel evolutionary opportunities to the organisms present, which ultimately led to the formation of our planet's major animal and plant species. 
Therefore, this "co-evolution" between organisms and their environment is an intrinsic feature of living systems. Life survives and sometimes thrives under what seem to be harsh conditions on Earth. For example, some microbes thrive at temperatures of $113^{\circ} \mathrm{C}$. Others exist only in highly acidic environments or survive exposures to intense radiation. While all organisms are composed of nearly identical macromolecules, evolution has enabled such microbes to cope with a broad range of physical and chemical conditions. What are the features that enable some microbes to thrive under extreme conditions that are lethal to many others? An understanding of the tenacity and versatility of life on Earth, as well as an understanding of the molecular systems that some organisms utilize to survive such extremes, will provide a critical foundation that will help us to understand the molecular adaptations that define the physical and chemical limits for life on Earth.

\section{Photosynthetic extremophiles}

When we think of extremophiles, prokaryotes come to mind first. Thomas Brock's pioneering studies of extremophiles carried out in Yellowstone's hydrothermal environments, set the focus of life in extreme environments on prokaryotes and their metabolisms (Brock, 1978). However, eukaryotic microbial life may be found actively growing in almost any extreme condition where there is a source of energy to sustain it, with the only exception of high temperature $\left(>70^{\circ} \mathrm{C}\right)$ and the deep subsurface biosphere (Roberts, 1999). The development of molecular technologies and their application to microbial ecology has increased our knowledge of eukaryotic diversity in many different environments (Caron et al., 2004). This is particularly relevant in extreme environments, generally more difficult to replicate in the laboratory.

Recent studies based on molecular ecology have demonstrated that eukaryotic organisms are exceedingly adaptable and not notably less so than the prokaryotes, although most habitats have not been sufficiently well explored for sound generalizations to be made. In fact, molecular analysis has also revealed novel protist genetic diversity in different extreme environments (Roberts, 1999).

Temperature is one of the main factors determining the distribution and abundance of species due to its effects on enzymatic activities (Alexandrof, 1977). Most extremophiles that survive at high temperatures $\left(95-115^{\circ} \mathrm{C}\right)$ are microorganisms from the archaeal or bacterial domains. On the contrary, for eukaryotic microorganisms, the highest temperature reported is $62^{\circ} \mathrm{C}$, and most of the metazoans are unable to grow above $50^{\circ} \mathrm{C}$ (Rothschild \& Mancinelli, 2001). Surprisingly, photosynthetic prokaryotes, such as cyanobacteria, have never been found in hot acidic aquatic systems (Brock, 1973). Instead, these ecological niches are usually profusely colonized by species of the order Cyanidiales, red unicellular algae (Brock, 1973). Thus, species from the genera Galdieria and Cyanidium have been isolated from hot sulfur springs, showing an optimal growth temperature of $45^{\circ} \mathrm{C}$ and a maximum growth temperature of $57^{\circ} \mathrm{C}$ (Seckbach, 1994; Ciniglia et al., 2004). These extreme hot springs are usually acidic (pH 0.05-4) and frequently characterized by high concentrations of metals such as cadmium, nickel, iron or arsenic, that are highly toxic to almost all known organisms.

Additionally, phototrophic eukaryotic microorganisms have colonized environments characterized by temperatures at or below $0^{\circ} \mathrm{C}$. Some algal species bloom at the snow surface during spring (Fujii et al., 2010), and complex microbial communities have been found on glaciers, probably the most widely studies environments after marine ice habitats. Aplanospores of Chlamydomonas nivalis are frequently found in high-altitude, persistent 


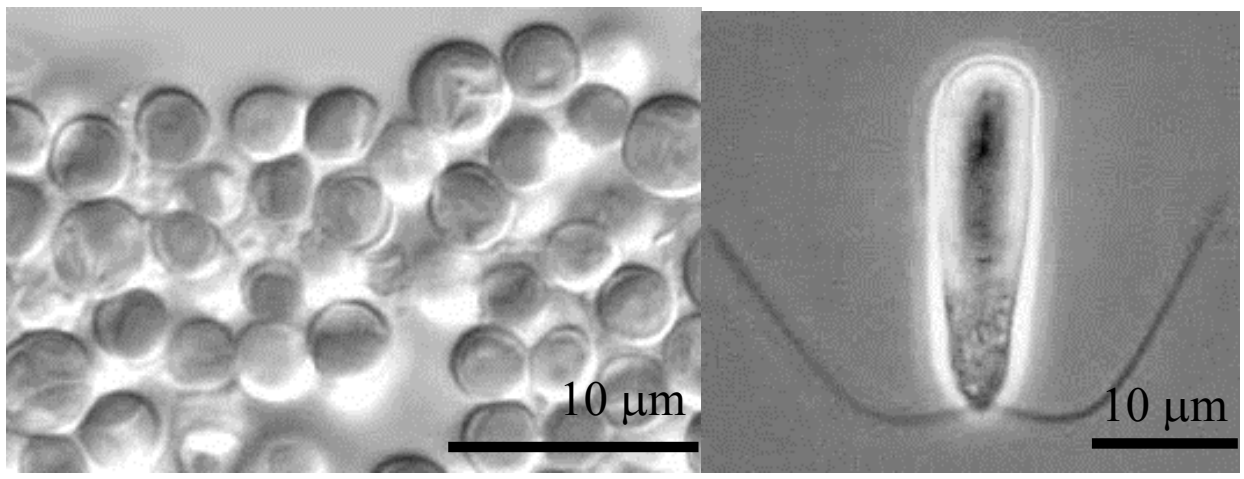

A

B

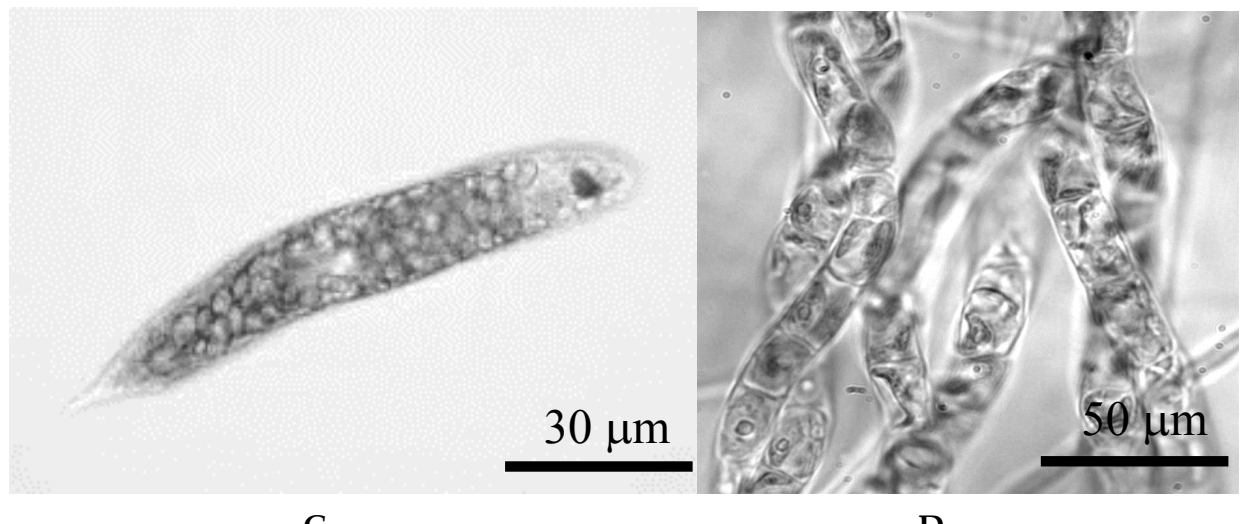

C

D

Fig. 1. Some examples of eukaryotic photosynthetic extremophiles. A.- Cyanidium caldarium, B.- Dunaliella salina, C.- Euglena mutabilis, D.- Klebsormidium sp.

snowfields where they are photosynthetically active despite cold temperatures and high levels of ultraviolet radiation (Stibal et al., 2006). Distinct microbial communities composed of psychrophilic bacteria, microalgae and protozoa colonize and grow in melt pools on the ice surface, or in brine channels in the sub-ice platelet in the Arctic even during winter, at extremely low temperatures of $-20^{\circ} \mathrm{C}$ (Garrison \& Close, 1993).

Non aquatic environments, where desiccation is common and water is a scarce resource, are also colonized by photosynthetic microorganisms. In these ecosystems, open spaces are usually covered by biological soil crusts, a highly specialized community of cyanobacteria, mosses and lichens. Without a doubt, the most colorful coatings on rocks are produced by lichens, a remarkable symbiotic relationship between microscopic algal cells and fungal filaments. Although lichens can also withstand extreme environmental conditions, they generally cannot survive as well in the dry, sun-baked deserts (Garthy, 1999). The most recurrent species of lichens found in deserts are the large colonies of the lime-green map lichen Rhizocarpon geographicum, the ashy-gray Aspicilia cinerea and the orange Caloplaca saxicola. They might be thousands of years old. In fact, the colorful chartreuse rock lichen Acarospora chlorophana may grow only a few millimeters per century. 
Besides photosynthetic eukaryotes, in extreme environments, phototrophic microorganisms such as cyanobacteria are also frequently found forming thick microbial mats. Cyanobacterial mats are found in a broad range of environments, some of which can be considered extreme, such as hypersaline ponds and lakes, thermal springs, dry and hot deserts and the cold environment of polar regions (Stal, 2000; Zakhia et al., 2007). These communities often dominate total ecosystem biomass and productivity, and must contend with persistent low temperatures, repeated freeze-thaw cycles and highly variable light, nutrient and osmotic regimes (Vincent, 2000). These extreme habitats typically exhibit spatial gradients of chemical and physical factors, including extreme variations in temperature or salinity over relatively short distances that may influence local community structure (Miller \& Castenholz, 2000; Nübel et al., 2001). In photosynthetic mats, daily shifts in oxygen production contribute to significant variation in depth-related chemical structure, including periodic hyperoxia near the surface and highly variable oxygen penetration (Des Marais, 2003).

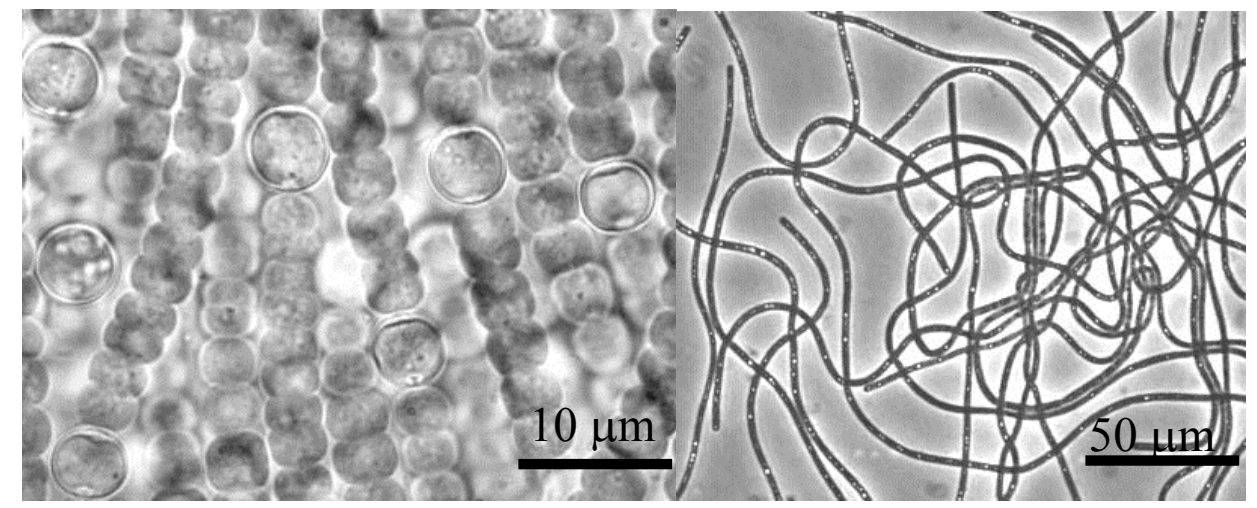

A

B

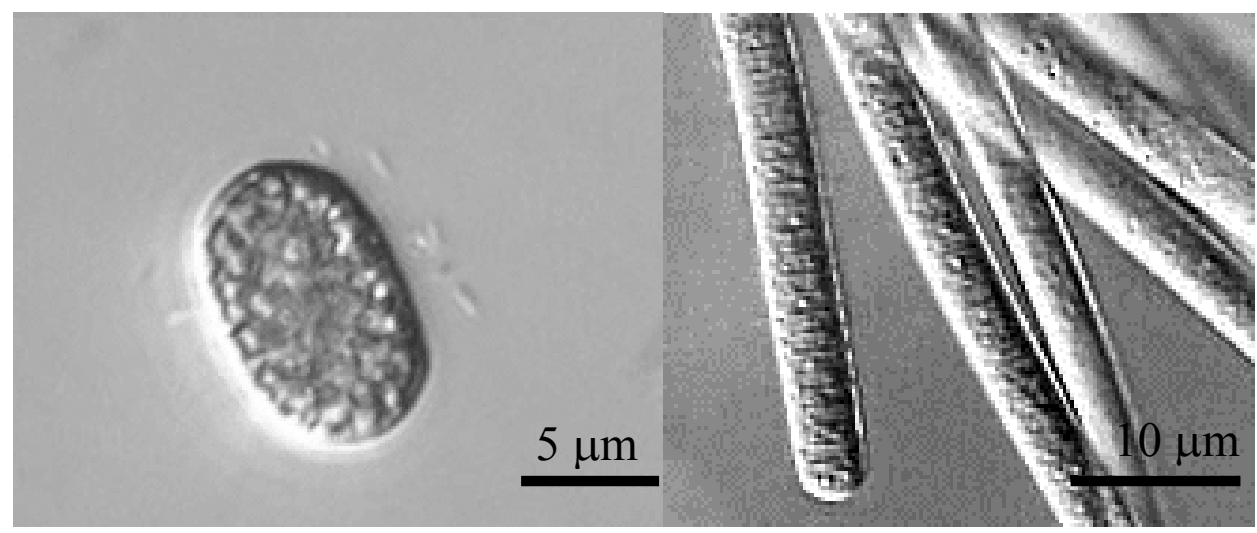

C

D

Fig. 2. Some examples of prokaryotic photosynthetic extremophiles. A.- Pseudoanabaena sp., B.- Chloroflexus sp., C.- Synechococcus sp., D.- Phormidium sp. 
Filamentous, mucilage-producing Oscillatoriales are responsible for much of the biomass and three-dimensional structure of these polar mat consortia. They have been shown to tolerate a wide range of conditions and to maintain slow net growth despite the frigid ambient temperatures (Tang et al., 1997; Jungblut, 2010). In addition, other cyanobacterial taxonomic groups are also present in cold environments. Species of the genus Phormidium, Pseudanabaena or Leptolyngbya are also wide distributed in the polar regions (FernándezValiente, 2007) (Fig.2). Usually, the photosynthetic rates per unit of chlorophyll a of the microbial mats formed by these species are low compared with other cyanobacterial communities from more temperate environments (Ariosa et al., 2006).

Hot springs are other extreme environment in which photosynthetic cyanobacteria can also be found. These springs are well-isolated habitats occurring as clusters in globally distant regions, and the microorganisms that inhabit them are extremophiles adapted to conditions quite different from the ambient. Thus, in well studied North American hot springs, such cyanobacterial mats are formed by rod-shaped unicellular cyanobacteria of the genus Synechococcus with an upper temperature limit of $72{ }^{\circ} \mathrm{C}$ (Papke et al., 2003) as well as the green nonsulfur bacterium Chloroflexus. Chloroflexus is a thermophilic filamentous anoxygenic phototrophic bacterium, and can grow phototrophically under anaerobic conditions or chemotrophically under aerobic and dark conditions. According to 16S rRNA analysis, Chloroflexi species are the earliest branching bacteria capable of photosynthesis, and they have been long regarded as a key organism to resolve the obscurity of the origin and early evolution of photosynthesis. Chloroflexi species contains a chimeric photosystem that comprises some characters of green sulfur bacteria and purple photosynthetic bacteria, and also has some unique electron transport proteins compared to other photosynthetic bacteria (Tang et al., 2011).

\section{Photosynthesis in extreme environments}

\subsection{Acidic environments. The Río Tinto (SW, Spain) case}

Highly acidic environments are relatively scarce worldwide and are generally associated with volcanic activity and mining operation (Baffico et al., 2004). The natural oxidation and dissolution of the sulfidic minerals exposed to oxygen and water results in acid production, and the process can be greatly enhanced by microbial metabolism (Nordstrom \& Southam, 1997; González-Toril et al., 2003). At the same time, low pH facilitates metal solubility in water, particularly cationic metals (such as aluminum and many heavy metals), and therefore acidic water tends to have high concentrations of heavy metals (Johnson, 1998).

Although low $\mathrm{pH}$ and high metals concentrations are restrictive to most aquatic life, large phototrophic biofilms and mats composed of filamentous green algae such Zygnemopsis or phototrophic protists such Euglena are often observed to thrive in extreme acidic environments (reviewed by Das et al., 2009a,b). Thus, acidic ecosystems are frequently colonized by organisms at an oligotrophic or mesotrophic level with dominant alga taxa belonging to the Crysophyceae, Chlorophyta and Bacillariophyta. These taxa are sometimes found in considerable quantities indicating a remarkable potential for primary production (Amaral-Zettler et al., 2002). Besides, presence of Klebsormidium sp. and Euglena mutabilis in a given environment is an ecological indicator of low $\mathrm{pH}$ and high level of metals (Valente \& Gomes, 2007).

Thus, since extreme acidic environments are often the consequence of anthropogenic influences (e.g., mining activity or acid rain), most ecological studies of acidic waters have 
been focused on environments affected by human activity. In this regard, Río Tinto (Iberian Pyritic Belt), is one of the most unique examples of extreme acidic environments, not only because of its natural origin (Fernández-Remolar et al., 2003), but also for its peculiar microbial ecology (Amaral et al., 2002). What makes Río Tinto a unique acidic extreme environment is the unexpectedly high degree of eukaryotic diversity found in its waters and that these eukaryotic organisms are the principal contributors to the biomass in the river (Aguilera et al., 2006a; Amaral et al., 2002). Over 65\% of the total biomass is due to photosynthetic protists. Members of the phylum Chlorophyta such as Chlamydomonas, Chlorella, and Euglena, are the most frequent species found followed by two filamentous algae belonging to the genera Klebsormidium and Zygnemopsis. The most acidic part of the river is inhabited by a eukaryotic community dominated by two species related to the genera Dunaliella (Chlorophyta) and Cyanidium (Rhodophyta), well known for their metal and acid
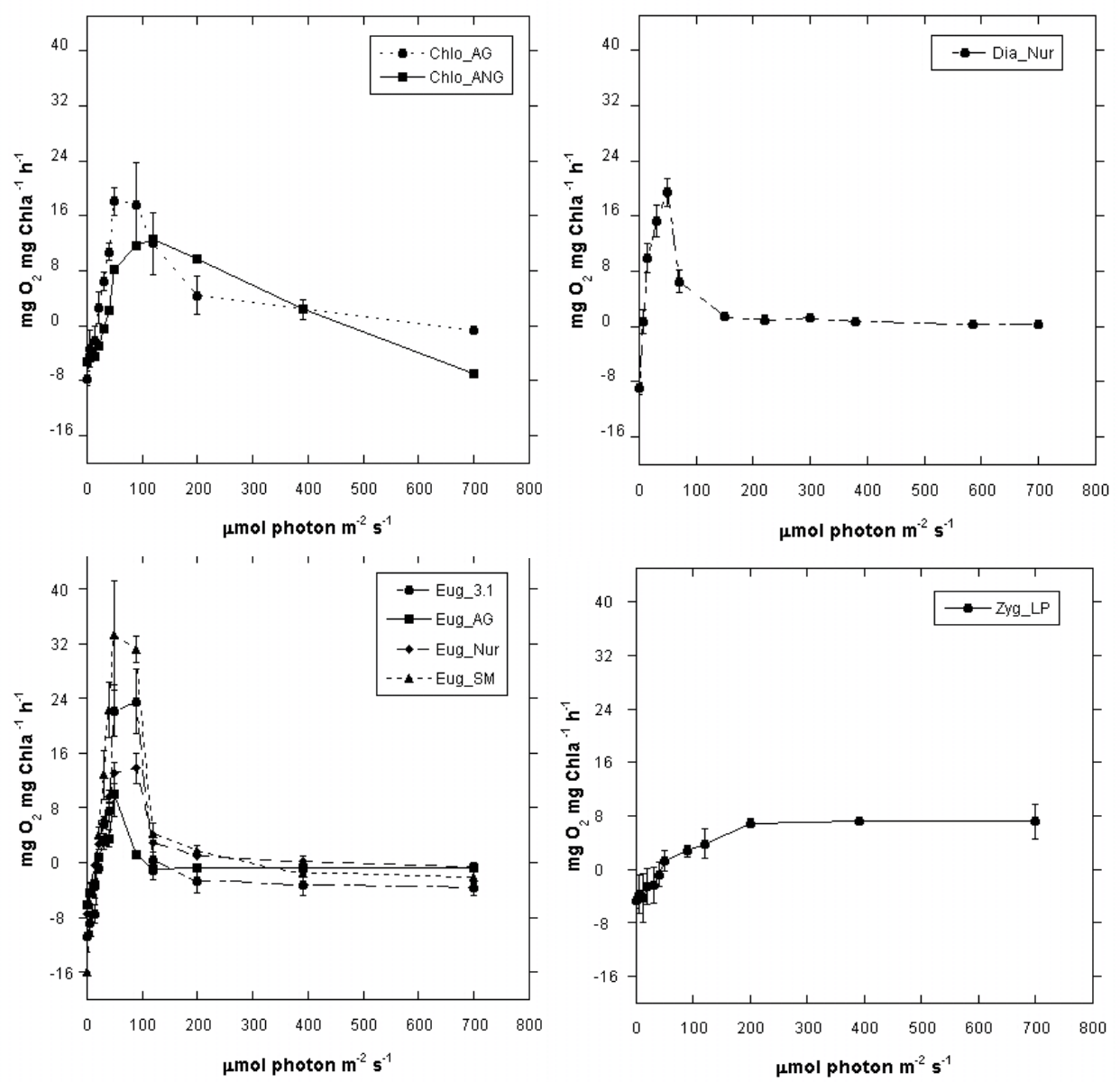

Fig. 3. Photosynthesis versus irradiance curves expressed on a $\mathrm{Chl} a$ basis $\left(\mathrm{mg} \mathrm{O}_{2} \mathrm{mg}^{-1} \mathrm{Chl} a\right.$ $\left.h^{-1}\right)$. Data are expressed as mean $\pm S D(n=3)$. 
tolerance. Molecular ecology techniques have identified algae closely related to those characterized phenotypically, emphazising the high degree of eukaryotic diversity existing in the extreme acidic conditions of the Tinto Basin (Aguilera et al., 2006b; Aguilera et al., $2006 \mathrm{~b})$. Most of the phototrophic microbial communities found in the river are distributed in extensive biofilms along the riverbed, mostly formed for one dominating species (Aguilera et al., 2007).

On the other hand, photosynthesis is known to be particularly sensitive to stressful environmental conditions, such as salinity, $\mathrm{pH}$ or presence of toxicants. There are relatively few reports regarding photosynthesis in acidic environments in the literature, and most have focused on primary productivity measurements in acidic lakes. Thus, its been reported that minimum primary productivity is mainly due to metal stress (Niyogi et al., 2002; Hamsher et al., 2002) or soluble reactive phosphate concentration (Spijkerman et al., 2007). However, low $\mathrm{pH}$ itself does not reduce photosynthetic activity (Gyure et al., 1987). Light is another limiting factor for primary productivity in acidic lakes. Adaptation to low light intensities has been reported for benthic biofilms of diatoms in acidic lakes (Koschorreck \& Tittle, 2002). To address this issue, the photosynthetic performance of different phototrophic biofilms isolated from Río Tinto was analyzed, in order to detect possible different photoadaptation capacities related to the environmental microhabitat conditions and the species composition of the biofilm. As far as we know this was the first attempt to determine the photosynthetic activity of low $\mathrm{pH}$ and heavy metal adapted phototrophic biofilms, which may give light in the understanding of the ecological importance of these organisms for the maintenance of the primary production of these extreme and unique ecosystems (Souza-Egipsy et al., 2011).

All the species analyzed showed a strong photoinhibition behaviour in their P-I curves except for the Zygemopsis sp. biofilm, which exhibited a photosaturated P-I curve behaviour. Generally, photoinhibition in P-I curves is commonly observed in shade adapted organisms, which cannot adequately dissipate the excessive photon flux provided by a high irrandiance (Platt et al., 1980).

In our case, the biofilms exhibiting photoinhibition (Euglena mutabilis, Pinnularia sp. and Chlorella sp.) are usually located at the bottom of the river bed, covered by several centimetres of a highly coloured red water. However, Zygnemopsis sp. is a filamentous algae usually found at the water surface during the summer, when the sun irradiance is extremely high, and in this way can be considered a high light adapted species.

In addittion, the analyzed species can be considered as low light or shade adapted organisms due to their low $\mathrm{I}_{\mathrm{c}}$ and $\mathrm{I}_{\mathrm{k}}$ values (Fig. 4), which may be related to the fact that they develop under highly coloured waters, that affect quantitatively and qualitatively the light available for phototrophic organisms. Even at irradiances as low as $5 \mathrm{mmol} \mathrm{m}^{-2} \mathrm{~s}^{-1}$, in the case of the diatom Pinnularia sp., photosynthetic activity was detected. These results are in agreement with previous data from sediments of acidic lakes, where photosynthetic ability at low light intensities $\left(<1.2 \mathrm{mE} \mathrm{m}^{-2} \mathrm{~s}^{-1}\right)$ were found in a benthic biofilm of diatoms suggesting an efficient absorption of red light, the dominant wavelength available in these iron-rich acidic waters, by these organisms (Koschorreck \& Tittle, 2002). Maximum photosynthesis values $\left(\mathrm{P}_{\max }\right)$ were also low in comparison with other environments, in

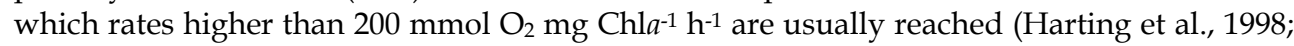
Ritchie, 2008). In acidic mining lakes, planktonic primary productivity is usually low probably due to the low phytoplankton biomass (Nixdorf et al., 2003). In our case, this cannot be the reason, since phototrophic biofilms are the principal contributors of biomass 
in Río Tinto, representing over 65\% of the total biomass (Lopez-Archilla et al, 2001). Another suggested reason for the low productivity in these extreme environments could be the lack of nutrients such as ammonium, phosphate or nitrate (Spijkerman et al., 2007).

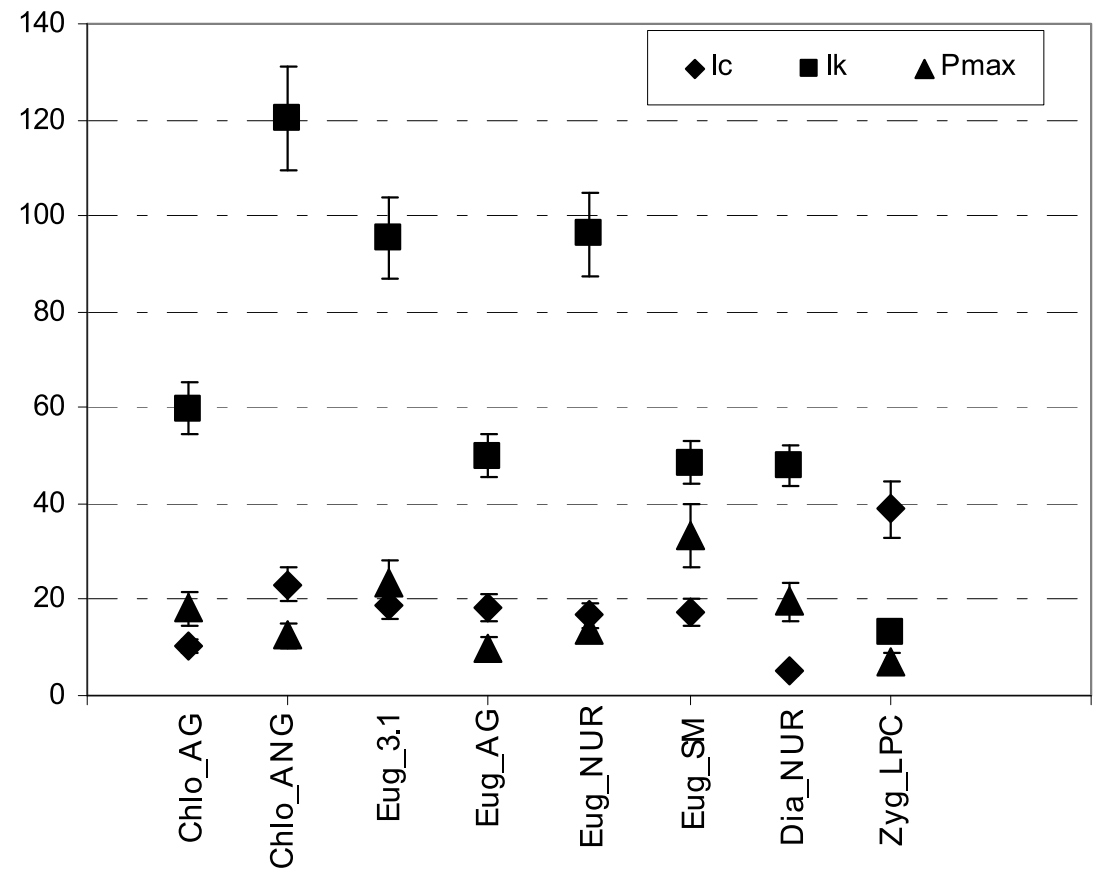

Fig. 4. Photosynthetic parameters of the different biofilms (Chlorella, Euglena, Diatom and Zygnemopsis) isolated from different locations at Río Tinto (AG, ANG, 3.1, NUR, SM and LPC). Compensation light intensity $\left(\mathrm{I}_{\mathrm{c}}\right)$ and light saturation parameter $\left(\mathrm{I}_{\mathrm{k}}\right)$ are expressed on photon basis ( $\mathrm{mmol}$ photons $\mathrm{m}^{-2} \mathrm{~s}^{-1}$ ). Maximum photosyntesis $\left(\mathrm{P}_{\max }\right)$ are expressed on $\mathrm{Chl} a$ basis (mg O $\left.\mathrm{mg} \mathrm{Chla}^{-1} a \mathrm{~h}^{-1}\right)$.

All the photosynthetic parameters analyzed showed statistical significant differences among species and sampling locations. Thus, the Euglena biofilms isolated from different habitats of the Río Tinto (3.1, AG, NUR, and SM) showed different photosynthetic values despite they are mainly formed by the same phototrophic species. The cells were able to maintain differences in their photosynthetic activity although all the experiments were carried out in artificial BG11 media, since the natural water from the river cannot be used in the oxymeter due to its high heavy metal concentrations. Following Falkowski \& La Roche (1991), these results could be explained by photoadaptation processes instead of photoacclimation procedures. Photoadaptation refers to changes in the genotype that arise either from mutations or from changes in the distribution of alleles within a gene pool, while photoacclimation refers to phenotypic adjustments that arise in response to variations of environmental factors.

Besides nutrient limitation, presence of high concentrations of heavy metals could also explain the low values of maximum photosynthetic activity, since inhibition of 
photosynthesis is one of the most important cellular responses to metal stress conditions (Hanikenne, 2003; Spijkerman et al., 2007). Thus, a significant decrease in the amount of some photosynthetic proteins (RuBisCo, cytrochrome C peroxidase or photosystem I 11K protein precursor ) has been reported in an isolate of Chlamydomonas spp. form Río Tinto when the cells were grown in natural metal rich water from the river (Cid et al., 2010). In this study, the metabolic response to metal-rich natural acidic waters from Río Tinto compared with artificial media was studied by determining proteomic differences between the two growth conditions. Although the cellular response induced by heavy metals on the growth and development of phytoplankton has been widely studied (Pinto et al., 2003; Gillet et al., 2006) most of these studies have focused on a single metal and most were carried out on freshwater algal species. However, little is currently known about heavy metal response in acidophilic organisms, despite the fact that they thrive in waters containing high levels of these toxicants.

To our knowledge, this was the first report regarding these issues using proteomic analysis of global expression patterns of cellular soluble proteins in an acidophilic strain of Chlamydomonas sp. Our results revealed that several stress-related proteins are induced in the cells growing in natural river water, along with a complex battery of proteins involved in photosynthesis, primary and energy metabolism or motility. When the 2-DE gels were compared, some of the most dramatic changes observed were related to proteins involved in the Calvin cycle and photosynthetic metabolism. In fact, three of the nine identified downregulated proteins found in cells grown in the presence of metals, were described from these metabolic pathways. The amount of the ribulose-1,5-bisphosphate carboxylase/oxygenase (RuBisCo) decreases significantly when cells grow in metal rich water (Fig. 5). This decrease correlates with other proteins described from photosynthesis, such us cytrochrome C peroxidase, oxygen-evolving enhancer protein or photosystem I $11 \mathrm{~K}$ protein precursor. These results are closely related to the presence of high levels of heavy metals present in the natural acidic waters since, inhibition of photosynthetic activity is one of the most important cellular responses to metal stress conditions (Hanikenne, 2003; Pinto et al., 2003). Similar results were found in $C$. reinhardtii in the presence of cadmium and copper (Boswell et al., 2002; Gillet et al., 2006), as well as in other photosynthetic organisms (Takamura et al., 1989; Wang et al., 2004). Although growth in extreme acidic environments is expected to require specific cellular adaptations of photosynthetic organisms, other studies have reported stress symptoms in acidophilic Chlamydomonas growing under acidic or metal-enriched natural water (Spijkerman et al., 2007; Langner et al., 2009).

On the contrary, phytochrome B, phosphoribulokinase and phosphoglycerate kinase were up-regulated when cells were grown in metal rich acidic water. Phytochromes are a family of light-sensing proteins required for plant developmental responses to light (Furuya, 1993; Quail, 1991). Plants perceive the intensity, direction, and quality of light and use this information to optimize photosynthesis. Phytochrome is the best characterized of the photoreceptors involved in these light dependent responses. In our case, the induction of this protein in the cells under study could be due to the intense red color of the Río Tinto water, caused by the high concentration of soluble ferric iron at the low $\mathrm{pH}$ of the river. This color has a marked effect on the quality and intensity of the light that reaches the cells. Experiments carried out in acidic mining lakes showed that only red light reaches the sediments of iron-rich water (Koschorreck \& Tittel, 2002). The increased levels of phytochrome could be an adaptation process to these environmental conditions. The remaining induced enzymes, phosphoglycerate kinase and phosphoribulokinase are 
described from carbon fixation metabolism in phototrophic organisms (Merchant et al., 2007). Similar results were found for $C$. reinhardtii under cadmium exposure suggesting a limitation of the photosynthetic electron transfer that might force the cell to reorganize its whole metabolism (Gillet et al., 2006).
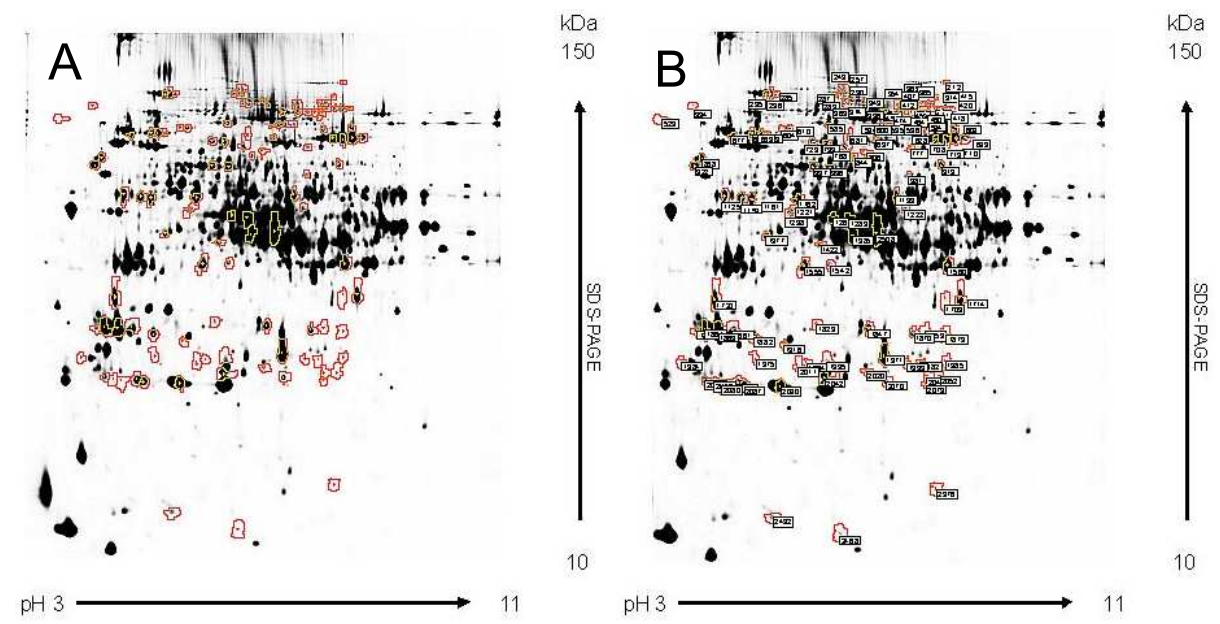

Fig. 5. 2-DE preparative gels. The spots resolved by 2-DE from preparative gels were stained with Coomassie Blue or with MALDI-MS-compatible silver reagent for peptide mass fingerprinting analysis. A)- gel obtained with cells growing under BG11/f2 artificial media at $\mathrm{pH} 2$. B)- gel obtained with cells growing under natural metal-rich water NW/f2 at $\mathrm{pH} 2$.

\subsection{Cold environments. Benthic phototrophic biofilms from Antarctica}

A very prevalent group of oxygenic phototrophs found in low-temperature environments are the Chromophytes, of which diatom algae in particular dominate marine and sea ice habitats. The diatoms possess a typical oxygenic photochemical apparatus; however, chlorophyll $b$ is replaced by chlorophyll $c$, and fucoxanthin is a major carotenoid (Green et al., 1996). Green algae play various roles in low-temperature environments, which are often more likely to be dominated by prokaryotic photosynthetic microorganisms. Notable exceptions are found in two divergent low-temperature environments, the alpine snow ecosystem, which is dominated by psychrophillic Chlamydomonas and Chloromonas spp., and the permanent ice-covered lakes of the McMurdo Dry Valleys, which are vertically stratified layers of green algae (Morgan-Kiss et al., 2006).

However, in the polar regions, cyanobacterial mats are the most widespread and abundant organisms in freshwater environments such as lakes, ponds, streams, glaciers, and ice shelves, and they often dominate the total biomass and biological productivity due to their adaptation to the polar environment (Vincent, 2000). The ubiquitous presence of cyanobacterial mats as well as their taxonomic composition and physiological activities in streams, ponds, lakes and melt-waters of different places in continental Antarctica are well documented (Fernández-Valiente et al., 2007; Jungblut et al., 2010). The ice shelves of the polar areas support shallow pond ecosystems that are created during the summer season when pockets of the ice melt to form bodies of liquid water of various sizes. While the 
formation of liquid water is seasonally transitory, the ponds often melt out in the same location every year, and the microorganisms, particularly the cyanobacterial microbial mats exhibit several decades of seasonal growth. The microorganisms that colonize these extreme habitats must be capable of surviving daily and annual freezing-thawing cycles, persistent low temperatures, continuously high exposure to solar radiation during the summer, and long periods of dormancy. Despite these constraints, there exist diverse and productive consortia of microorganisms in the form of microbial phototrophic mats. These biota are representative modern-day examples of how life survived and evolved during global glaciations and extended periods of extreme cold (Vincent et al., 2000).

Nevertheless, in the area of the maritime Antarctica these aspects are less well defined. This region is characterized by a less extreme climatic regime than other Antarctic areas, with higher mean temperatures and precipitation (Camacho, 2006). These climatic conditions as well as the complex geology lead to a great variety of water bodies and to a high number of ice-free freshwater ecosystems during summer months. Taxonomical studies of microbial mats in Antarctic Peninsula (Vinocur \& Pizarro, 1995) and King George Island (Vinocur \& Pizarro, 2000) showed a richer species composition than in continental Antarctica, reflecting the broad range of physical and chemical conditions of the studied lakes and ponds. Polar cyanobacteria withstand the extremes of their environment through production of photoprotective screening and quenching pigments, as well as by their highly efficient lightcapturing systems, nutrient storage ability and freeze-thaw tolerance (Hawes \& Schwarz, 2001; Zakhia et al., 2007).

In 2011, we carried out several in situ studies investigating the photosynthetic characteristics of aquatic microbial mats and biofilms ecosystems from in King George island (South Shetland Islands) and to evaluate their sensitivity to potential climate change.

The microbial mats analyzed were mainly dominated by filamentous cyanobacteria of the order Oscillatoriales (Oscillatoria sp. and Phormidium sp.) and Nostocales. Microbial mats are extremely abundant in Byers Peninsula, particularly in the puddle soils of the catchment areas and at the bottom of small lakes and ponds of the central plateau, where they formed large expanses up to several hundred square metres in extent. In the coastal areas, microbial mats are usually restricted to the shore and bottom of the streams as the flat lowlands are covered by extensive carpets of mosses and in some areas by the vascular plants Deschampsia antarctica and Colobanthus quitensis. The photosynthetic rates per unit of chlorophyll a of the mats analyzed were low compared with other cyanobacterial communities of more temperate environments (Ariosa et al., 2006), but are in the range of other Antarctic microbial mats (Howard-Williams et al., 1989; Davey, 1993; Vincent et al., 1993). It is possible that the depth layers where photosynthesis reached its maximal values and the overcast weather conditions of this region are conducive to a low $P_{\max }$ and $\alpha$, which were lower and higher, respectively, than in other cyanobacterial communities. Low $\mathrm{P}_{\max }$, low Ek and high a values are characteristics of photosynthesis in a shaded environment (Boston \& Hill, 1991).

The polar areas are one of the environments most vulnerable to climate warming, increasing global temperatures has already had a significant negative impact on accelerating the fragmentation and loss of the ice shelf. For that reason, in this study, our aim was to compare how the temperature leads photosynthetic performance in these microbial mats (Fig.6). In general, we can conclude that these mats showed higher photosynthetic rates at high temperatures (ca. $20^{\circ} \mathrm{C}$ ). Tang et al. (1997) found that many of the Arctic and Antarctic 
mat-forming cyanobacteria are not psychrophilic and exhibit growth temperature optima far above the temperatures found in their natural environments. Therefore it appears that adaptation to growth at low temperatures is not a requirement for successful colonization of these habitats, and other characteristics, such as UV screening and protection against photoinhibition, may have a greater selective advantage in the Arctic ice shelf environment. In addition, analysis of 16S rRNA genes from oscillatorians isolated from Antarctic and Arctic ice-shelf microbial mat communities indicates that filamentous cyanobacteria in both polar environments originated from temperate species (Nadeau et al., 2001).

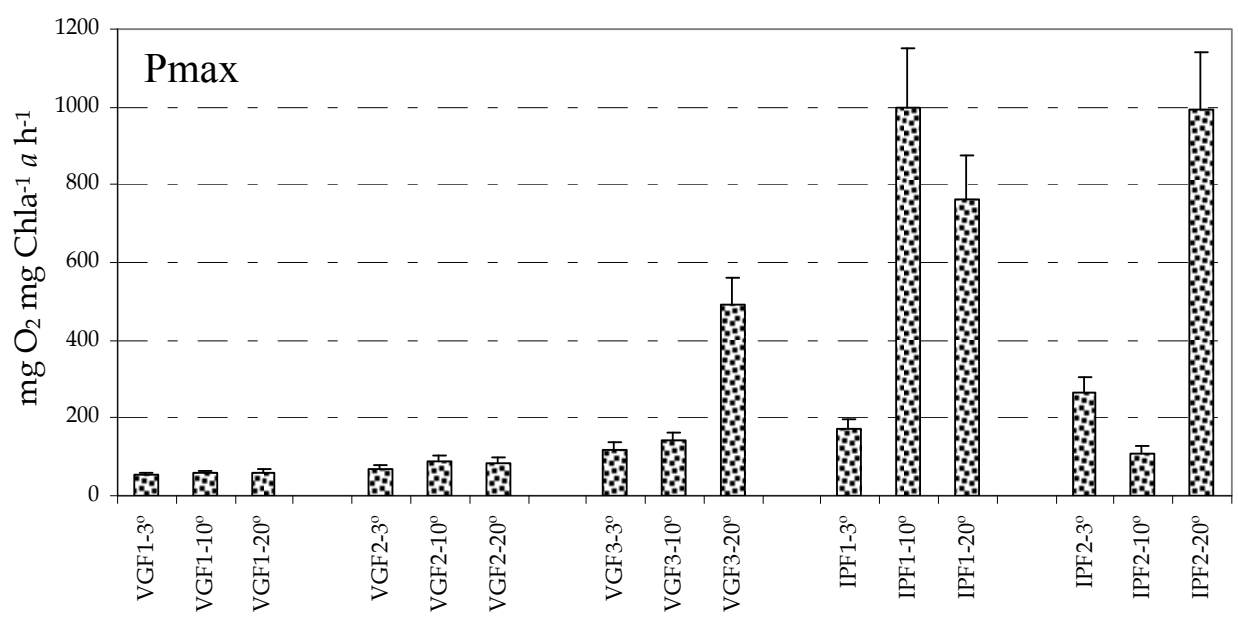

Fig. 6. Maximal photosynthetic rates of the different microbial mats isolated in King George island

\section{Conclusion}

In summary, although considerable work is yet to be done to understand the metabolism under extreme acidic environmental conditions, our results have shown that low-light adaptation of the phototrophic species could be an important determinant in the competitive success for colonizing these environments. Our work represents, we believe, the first attempt to use a proteomic approach to analyze the effects of acidic metal-rich natural water on one species adapted to these stress conditions. It demonstrates that naturally occurring metal rich water induces a stress response in acidophilic Chlamydomonas forcing algal cells to vary, not only their photosynthetic systems, but also to reorganize their metabolic pathways as an adaptive response to these environmental conditions, mainly driven by the high levels of heavy metals. Although further molecular and biochemical studies will properly elucidate the photosynthetic adaptation mechanisms to acidic waters, this study provides important information concerning these response pathways at the protein level, which are the fundamental functioning molecules in the cells.

In addition, permanently cold ecosystems make up one of the largest biospheres on the Earth. Paradoxically, the microorganisms that not only survive but thrive in these extreme 
habitats are still poorly understood. These two factors make low-temperature environments one of the last unexplored frontiers in our world. Research regarding the physiology and biochemistry of the primary producers, the microorganisms relying on photoautotrophic metabolism, of many of the food webs is still scarce.

Genome sequencing is the next step in understanding the adaptation of microorganisms to life in extreme environments, although a more powerful tool will be the integration of genomics with metabolic function through physiological and biochemical investigations. Therefore, our sequencing efforts should focus on extremophilic phototrophic genomes in order to achieve a better knowledge regarding the natural ecology, physiology, and biochemistry of these environments.

\section{Acknowledgment}

This work has been supported by the Spanish Science and Innovation Grants CGL200802298/BOS and CGL2009-08648-E.

\section{References}

Aguilera, A.; Manrubia, S.C.; Gómez, F.; Rodríguez, N. \& Amils, R. (2006a). Eukaryotic community distribution and their relationship to water physicochemical parameters in an extreme acidic environment, Río Tinto (SW, Spain). Applied and Environmental Microbiology, Vol.72, pp.5325-5330

Aguilera, A.; Gómez, F.; Lospitao, E. \& Amils, R. (2006b). A molecular approach to the characterization of the eukaryotic communities of an extreme acidic environment: methods for DNA extraction and denaturing gradient electrophoresis analysis. Systematic and Applied Microbiology, Vol.29, pp.593-605

Aguilera, A.; Souza-Egipsy, V.; Gómez, F. \& Amils, R. (2007a) Development and structure of eukaryotic biofilms in an extreme acidic environment, Río Tinto (SW, Spain). Microbial Ecology, Vol. 53,pp.294-305

Alexandrof, V.Y. (1977). Cells, molecules and temperature. Conformational flexibility of macromolecules and ecological adaptations. Springer-Verlag, Berlin, Germany

Amaral, L.A.; Gómez, F.; Zettler, E.; Keenan, B.G.; Amils, R. \& Sogin, M.L. (2002) Eukaryotic diversity in Spain's river of fire. Nature, Vol. 417, pp.137

Ariosa, Y.; Carrasco, D.; Quesada, A. \& Fernández-Valiente, E. (2006). Incorporation of different $\mathrm{N}$ sources and light response curves of nitrogenase and photosynthesis by cyanobacterial blooms from rice fields. Microbial Ecology, Vol.51, pp.394-403

Baffico, G.D.; Díaz, M.M.; Wenzel, M.T.; Koschorreck, M.; Schimmele, M.; Neu, T.R. and Pedrozo, F. (2004) Community structure and photosynthetic activity of epilithon from a highly acidic $(\mathrm{pH}<2)$ mountain stream in Patagonia, Argentina. Extremophiles, Vol.8, pp.465-475

Boston, H.L. \& Hill, W.R. (1991). Photosynthesis-light relations of stream periphyton communities. Limnology and Oceanography, Vol.36, pp.644-656

Boswell, C.; Sharma, N.C. \& Sahi, S.V.. (2002). Copper tolerance and accumulation potential of Chlamydomonas reinhardtii. Bulletin of Environmental Contamination Toxicology, Vol.69, pp.546-553

Brock, T. (1973). Lower $\mathrm{pH}$ limit for the existence of blue-green algae: Evolutionary and ecological implications. Science, Vol.179, pp. 480-483 
Brock, T. (1978). Thermophilic Microorganisms and Life at High Temperatures, Springer-Verlag, New York.

Camacho, A. (2006). Planktonic microbial assemblages and the potential effects of metazooplankton predation on the food web of lakes of the maritime Antarctica and Subantarctic Islands. Reviews in Environmental Science and Biotechnology, Vol.5, pp.167-185

Caron, D.A.; Countway, P.D. \& Brown, M.V. (2004) The growing contributions of molecular biology and immunology to protistan ecology: molecular signatures as ecological tools. Journal of Eukaryotic Microbiology, Vol.51, pp.38-48

Cid, C.; Garcia-Descalzo, L.; Casado-Lafuente, V.; Amils, R. \& Aguilera, A. (2010). Proteomic analysis of the response of an acidophilic strain of Chlamydomonas sp. (Chlorophyta) to natural metal-rich water. Proteomics, Vol.10, pp.2026-2036

Ciniglia, C.; Yoon, H.S.; Pollio, A.; Pinto, G. \& Bhattacharya, D. (2004). Hidden biodiversity of the extremophilic Cyanidiales red algae. Molecular Ecology, Vol.13, pp.1827-1838

Das, B.K.; Roy, A.; Koschorrech, M.; Mandal, S.M.; Wendt-Potthoff, K. \& Bhattacharya, J. (2009a). Occurrence and role of algae and fungi in acid mine drainage environment with special reference to metals and sulphate immobilization. Water Research, Vol.43, pp.883-894

Das, B.K.; Roy, A.; Singh, S. \& Bhattacharya, J. (2009b) Eukaryotes in acidic mine drainage environments: potential applications in bioremediation. Reviews in Environmental Science Biotecnology, Vol. 8, pp.257-274

Davey, M.C. (1993). Carbon and nitrogen dynamics in a maritime Antarctic stream. Freshwater Biology, Vol.30, pp.319-330

De los Ríos, A.; Ascaso, C.; Wierzchos, J.; Fernández-Valiente, E. \& Quesada, A. (2004). Microstructural characterization of cyanobacterial mats from the McMurdo Ice Shelf, Antarctica. Applied and Environmental Microbiology, Vol.70, pp.569-580

Des Marais, D.J. (2003). Biogeochemistry of hypersaline microbial mats illustrates the dynamics of modern microbial ecosystems and the early evolution of the biosphere. Biological Bulletin, Vol..204, pp.160-167

Falkowski, P.G. \& La Roche, J. (1991) Acclimation to spectral irradiance in algae. Journal of Phycology, Vol. 27, pp.8-14

Fernández-Remolar, D.C.; Rodríguez, N.; Gómez, F. \& Amils, R. (2003) Geological record of an acidic environment driven by the iron hydrochemistry: the Tinto river system. Journal of Geophysical Research, Vol.108, pp.5080-5095

Fernández-Valiente, E.; Camacho, A.; Rochera, C.; Rico, E.; Vincent, W.F. \& Quesada, A. (2007). Community structure and physiological characterization of microbialmats in Byers Peninsula, Livingston Island (SouthShetland Islands, Antarctica). FEMS Microbiology and Ecology, Vol.59, pp. 377-385

Fujii, M.; Takano, Y.; Kojima, H.; Hoshino, T.; Tanaka, R. \& Fukui, M. (2010). Microbial community structure, pigment composition, and nitrogen source of red snow in Antarctica. Microbial Ecology, Vol.59, No.3, pp.466-475

Furuya, M. (1993). Phytochromes: their molecular species, gene families, and functions. Annual Review in Plant Physiology and Plant Molecular Biology, Vol.44, pp.617-641

Garrison, D.L. \& Close, A.R. (1993). Winter ecology of the sea ice biota in Weddel Sea pack ice. Marine Ecolology Progress Series, Vol.96, pp. 17-31 
Garthy, J. (1999). Lithobionts in the eastern mediterranean. In: Enigmatic Microorganisms and Life in Extreme Environments, Seckbach, J. (Ed.), 257-276, Kluwer Academic Publ. London, England

González-Toril, E.; Llobet-Brossa, E.; Casamayor, E.O.; Amann, R. \& Amils, R. (2003). Microbial ecology of an extreme acidic environment. The Tinto River. Applied and Environmental Microbiology, Vol.69, pp. 4853-4865

Gillet, S.; Decottignies, P.; Chardonnet, S. \& Maréchal, P. (2006). Cadmium response and redoxin targets in Chlamydomonas reinhardtii: a proteomic approach. Photosynthesis Research, Vol.89, pp.201-211

Green, B.R. \& Durnford, D.G. (1996). The chlorophyll-carotenoid proteins of oxygenic photosynthesis. Annual Reviews in Plant Physiology and Plant Molecular Biology, Vol.47, pp.685-714

Guyre, R.A.; Konopka, A.; Brooks, A. \& Doemel, W. (1987). Algal and bacterial activities in acidic (ph3) strip mine lakes. Applied and Environmental Microbiology, Vol.53, pp.2069-2076

Hanikenne, M. (2003). C. reinhardtii as a eukaryotic photosynthetic model for studies of heavy metal homeostasis and tolerance. New Phytologist, Vol..159, pp.331-340

Harting, P.; Wolfstein, K.; Lippemeier, S. \& Colijn, F. (1998). Photosynthetic activity of natural microbenthos populations measured by fluorescence PAM and ${ }^{14} \mathrm{C}$-tracer: a comparison. Marine Ecology Progress Series, Vol.166, pp.53-62

Hawes, I. \& Schwarz, A.M. (2001). Absorption and utilization of irradiance by cyanobacterial mats in two icecovered Antarctic lakes with contrasting light climates. Journal of Phycology, Vol.37, pp.5-15

Horikoshi, K. (1998) Barophiles: deep-sea microorganisms adapted to an extreme environment. Current Opinion in Microbiology, Vol.1, No.3, pp. 291-295

Howard-Williams, C.; Pridmore, R.D.; Downes, M.T. \& Vincent. W.F. (1989). Microbial biomass, photosynthesis and chlorophyll a related pigments in the ponds of the McMurdo Ice Shelf, Antarctica. Antarctic Science, Vol.1, pp.125-131

Johnson, D.B. (1998). Biodiversity and ecology of acidophilic microorganisms. FEMS Microbiology Ecolology, Vol.27, pp.307-317

Jungblut, A.D.; Lovejoy, C. \& Vincent, W.F. (2010). Global distribution of cyanobacterial ecotypes in the cold biosphere. The ISME Journal, Vol.4, pp. 191-202

Koschorrek, M. \& Tittel, J. (2002). Benthic photosynthesis in acidic mining lake (pH. 2.6). Limnololy and Oceanography, Vol.47, No.4, pp.1197-1201

Langner, U.; Jakob, T.; Stehfest, K. \& Wilhelm, C. (2009). An energy balance from absorbed protons to new biomass for $C$. reinhardtii and C. acidophila under neutral and extremely acidic growth conditions. Plant Cell Environment, Vol.32, pp.250-258

Lebedinsky, A.V.; Chernyh, N.A. \& Bonch-Osmolovskaya, E.A. (2007). Phylogenetic systematics of microorganisms inhabiting thermal environments. Biochemistry, Vol.72, No.12, pp.1299-1312

López-Archilla, A.I.; Marín, I. \& Amils, R. (2001). Microbial community composition and ecology of an acidic aquatic environment: the Tinto river, Spain. Microbial Ecology, Vol.41, pp.20-35

Ma, Y.; Galinski, E.A.; Grant, W.D.; Oren, A. \& Ventosa, A. (2010). Halophiles 2010: life in saline environments. Applied and Environmental Microbiology, Vol.76, No.21, pp. 6971-6981 
Merchant, S.; Prochnik, S.E.; Vallon, O. \& Harris, E.H. (2007). The Chlamydomonas genome reveals the evolution of key animal and plant functions. Science, Vol.318, pp.245-251

Miller, S.R. \& Castenholz, R.W. (2000). Evolution of thermotolerance in hot spring cyanobacteria of the genus Synechococcus. Applied and Environmental Microbiology, Vol.66, pp.4222-4229

Morgan-Kiss, R.M.; Priscu, J.C; Pocock, T.; Gudynaite-Savitch, L. \& Huner, N.P (2006). Adaptation and acclimation of photosynthetic microorganisms to permanently cold environments. Microbiology and Molecular Biology Reviews, Vol.70, No.1, pp.222-252

Nadeau, T.L.; Milbrandt, E.C. \& Castenholz, R.W. (2001). Evolutionary relationships of cultivated Antarctic oscillatorians (cyanobacteria). Journal of Phycology, Vol.37, pp.650-654

Niyogi, D.K.; Lewis, W.M. \& McKnight, D.M. (2002). Effects of stress from mine drainage on diversity, biomass, and function of primary producers in mountain streams. Ecosystems, Vol.5, pp. 554-567

Nixdorf, B.; Krumbeeck, H.; Jander, J. \& Beulker, C. (2003). Comparison of bacterial and phytoplankton productivity in extremely acidic mining lakes and eutrophic hard water lakes. Acta Oecologica, Vol.24, pp.S281-S288

Nordstrom, D.K. \& Southam, G. (1997). Geomicrobiology of sulphide mineral oxidation, In: Geomicrobiology:Iinteractions Between Microbes and Minerals, J.F. Banfield \& K.H. Nealson (Eds.), 361-390, Mineralogical Society of America, Washington DC, USA

Nübel, U.; Bateson, M.M.; Madigan, M.T.; Kuhl, M. \& Ward, D.M. (2001). Diversity and distribution in hypersaline microbial mats of bacteria related to Chloroflexus spp. Applied and Environmental Microbiology, Vol.67, pp.4365-4371

Papke, R.T., Ramsing, N.B., Bateson, M.M. \& Ward, D.M. (2003). Geographical isolation in hot spring cyanobacteria. Environmental Microbiology, Vol. 5, No.8, pp. 650-659

Pinto, E.; Sigaud-Kutner, T.; Leitão, M.; Okamoto, O. (2003). Heavy-metal induced oxidative stress in algae. Journal of Phycology, Vol.39, pp.1008-1018

Platt, T.; Gallegos, C.L. and Harrison, W.G. (1980). Photoinhibition of photosynthesis in natural assemblages of marine phytoplankton. Journal of Marine Research, Vol. 38, pp.687-701

Pointing, S.B.; Chan, Y.; Lacap, D.C.; Lau, M.C.; Jurgens, J.A. \& Farrell, R.L. (2009).Highly specialized microbial diversity in hyper-arid polar desert. Proceedings of the National Academy of Science USA, Vol.106, No.47, pp.19964-19969

Quail, PH. (1991). Phytochrome: a light-activated molecular switch that regulates plant gene expression. Annual Reviews in Genetic, Vol.25, pp.389-409

Ritchie, R.J. (2008). Fitting light saturation curves measured using modulated fluorometry. Photosynthesis Research, Vol.96, pp.201-215

Roberts, D.M.L. (1999). Eukaryotic cells under extreme conditions, In: Enigmatic Microorganisms and Life in Extreme Environments, J. Seckbach (Ed.), 165-173, Kluwer Academic Publ., London, England

Rothschild, L.J. \& Mancinelli, R.L. (2001). Life in extreme environments. Nature, Vol.409, pp. 1092-1101

Seckbach, J. (1994). Evolutionary pathways and enigmatic algae: Cyanidium caldarium (Rhodophyta) and related cells. In: Developments in Hydrobiology, Seckbach, J. (Ed.), 245-255, Kluwer Academic Publ., Dordrecht 
Souza-Egipsy, V.; Altamirano, M.; Amils R. \& Aguilera, A. (2011). Photosynthetic performance of phototrophic biofilms in extreme acidic environments. Environmental Microbiology, DOI: 10.1111/j.1462-2920.2011.02506.x

Spijkerman, E.; Barua, D.; Gerloff-Elias, A.; Kern, J.; Gaedke, U. \& Heckathorn, S.A. (2007). Stress responses and metal tolerance of Chlamydomonas acidophila in metal-enriched lake water and artificial medium. Extremophiles, Vol.11, pp.551-562

Stal, L.J. (2000). Cyanobacterial mats and stromatolites. The Ecology of Cyanobacteria: Their Diversity in Time and Space, B.A. Whitton \& M. Potts, (Eds.), Kluwer Academic Press, Dordrecht

Stibal, M., Elster, J., Šabacká, M. \& Kaštovská, K. (2006). Seasonal and diel changes in photosynthetic activity of the snow alga Chlamydomonas nivalis (Chlorophyceae) from Svalbard determined by pulse amplitude modulation fluorometry. FEMS Microbiology and Ecology, Vol.59, pp.265-273

Takamura, N.; Kasai, F.; Watanabe, M.M. (1989). Effects of Cu, Cd and Zn on photosynthesis of fresh water benthic algae. Journal of Applied Phycology, Vol.1, pp.39-52

Tang, E.P.Y.; Tremblay, R. \& Vincent, W.F. (1997). Cyanobacterial dominance of polar freshwater ecosystems: are high-latitude mat-formers adapted to low temperature? Journal of Phycology, Vol.33, pp.171-181

Tang, K.H.; Barry, K.; Chertkov, O.; Dalin, E.; Han, C.S.; Hauser, L.J.; Honchak, B.M.; Karbach, L.E.; Land, M.L.; Lapidus, A.; Larimer, F.W.; Mikhailova, N.; Pitluck, S.; Pierson, B.K.; Blankenship, R.E. (2011). Complete genome sequence of the filamentous anoxygenic phototrophic bacterium Chloroflexus aurantiacus. BMC Genomics, Vol.12, No.1, pp.334

Taton, A.; Grubisic, S.; Balthasart, P.; Hodgson, D.A.; Laybourn-Parry, J. \& Wilmotte, A. (2006). Biogeographical distributionand ecological ranges of benthic cyanobacteria inEastAntarctic lakes. FEMS Microbiology and Ecology, Vol.57, No.2, pp. 272-289

Valente, T.M. \& Gomes, C.L. (2007). The role of two acidophilic algae as ecological indicators of acid mine drainage sites. Journal of Iberian Geology, Vol. 33, pp.283-294

Vincent, W.F.; Castenholz, R.W.; Downes, M.T. \& Howard-Williams, C. (1993). Antarctic cyanobacteria: light, nutrients, and photosynthesis in the microbial mat environment. Journal of Phycology, Vol.29, pp.745-755

Vincent, W.F. (2000). Cyanobacterial dominance in the polar regions. In: The Ecology of Cyanobacteria, B.A. Whitton \& M. Potts (Eds.), 321-340, Kluwer Academic Publishers, Dordrecht, The Netherlands

Vincent, W. F.; Gibson, J.A.; Pienitz, R.; Villeneuve, V.; Broady, P.A.; Hamilton, P.B. \& Howard-Williams, C. (2000). Ice shelf microbial ecosystems in the high arctic and implications for life on snowball earth. Naturwissenschaften, Vol.87, pp.137-141

Vinocur, A. \& Pizarro, H. (1995). Periphyton flora of some lotic and lentic environments of Hope Bay (Antarctic Peninsula). Polar Biology, Vol.15, pp.401-414

Vinocur, A. \& Pizarro, H. (2000). Microbial mats of twenty-six lakes from Potter Peninsula, King George Island, Antarctica. Hydrobiologia, Vol.437, pp.171-185

Wang, S.; Chen, F.; Sommerfeld, M. \& Hu, Q. (2004). Proteomic analysis of molecular response to oxidative stress by the green alga Haematococcus pluvialis (Chlorophyceae). Planta, Vol.220, pp.17-29 
Zakhia, F.; Jungblut, A.D.; Taton, A.; Vincent, W.F. \& Wilmotte, A. (2007). Cyanobacteria in cold environments. In: Psychrophiles: from Biodiversity to Biotechnology, R. Margesin, F. Schinner \& J.C. Marx (Eds,), 121-135, Springer-Verlag, Berlin, Germany 


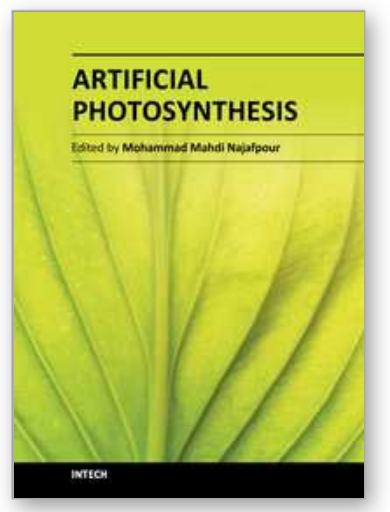

\author{
Artificial Photosynthesis \\ Edited by Dr Mohammad Najafpour
}

ISBN 978-953-307-966-0

Hard cover, 288 pages

Publisher InTech

Published online 24, February, 2012

Published in print edition February, 2012

Photosynthesis is one of the most important reactions on Earth, and it is a scientific field that is intrinsically interdisciplinary, with many research groups examining it. We could learn many strategies from photosynthesis and can apply these strategies in artificial photosynthesis. Artificial photosynthesis is a research field that attempts to replicate the natural process of photosynthesis. The goal of artificial photosynthesis is to use the energy of the sun to make different useful material or high-energy chemicals for energy production. This book is aimed at providing fundamental and applied aspects of artificial photosynthesis. In each section, important topics in the subject are discussed and reviewed by experts.

\title{
How to reference
}

In order to correctly reference this scholarly work, feel free to copy and paste the following:

Angeles Aguilera, Virginia Souza-Egipsy and Ricardo Amils (2012). Photosynthesis in Extreme Environments, Artificial Photosynthesis, Dr Mohammad Najafpour (Ed.), ISBN: 978-953-307-966-0, InTech, Available from: http://www.intechopen.com/books/artificial-photosynthesis/photosynthesis-in-extreme-environments

\section{INTECH}

open science | open minds

\section{InTech Europe}

University Campus STeP Ri

Slavka Krautzeka 83/A

51000 Rijeka, Croatia

Phone: +385 (51) 770447

Fax: +385 (51) 686166

www.intechopen.com

\section{InTech China}

Unit 405, Office Block, Hotel Equatorial Shanghai

No.65, Yan An Road (West), Shanghai, 200040, China

中国上海市延安西路65号上海国际贵都大饭店办公楼405单元

Phone: +86-21-62489820

Fax: +86-21-62489821 
(C) 2012 The Author(s). Licensee IntechOpen. This is an open access article distributed under the terms of the Creative Commons Attribution 3.0 License, which permits unrestricted use, distribution, and reproduction in any medium, provided the original work is properly cited. 